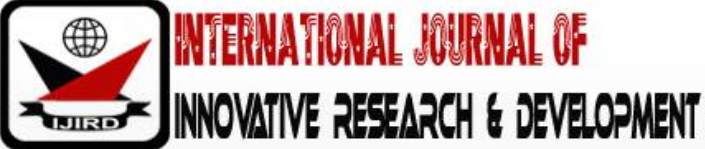

ISSN 2278-0211 (Online)

\section{Estimation of Overburden and Estimation of Mineable of Coal Reserved on Pit at Area B III Warute South at Coal Contract of Work (CCOW) Pt. Antang Gunung Meratus Sungai Raya Sub- District, Hulu Sungai Selatan District East Kalimantan}

Dr. Sakdillah
Lecturer, Department of Mining Engineering
Mulawarman University Samarinda, East Kalimantan, Indonesia
Hamzah Umar
Lecturer, Department of Mining Engineering,
Mulawarman University, Samarinda, Indonesia
Azarya Ardfensone Depari
Student, Department of Engineering,
Mulawarman University Samarinda, East Kalimantan, Indonesia

\begin{abstract}
:
In accordance with technological advances in the field of mining, nowadays more and more computerized -based programs that can facilitate the work of modeling and calculation of reserves and mining of various kinds of designs. These programs were created to support the work on the basis of the work that does not change the basic concept and philosophy of the calculation. Detail research was performed on pit at area B III warute south At Coal Contract Of Work (CCoW) PT. Antang Gunung Meratus Sungai Raya Sub-District, Hulu Sungai Selatan District East Kalimantan Province. Estimation of overburden and mineable coal reserves through of redesign of mining pit was conducted using the cross section method with computerized software system autocad 2007 and minescape 4.1.1.9Estimation of overburden and Mineable coal reserved calculation performed on the main seam M4. The M4 seam shows varying thickness of coal, with a wavy layer structure and split. The slope of coal in the study area is generally relatively steep, which is in the range $38^{\circ}-42^{\circ}$ with the strike direction of the $N 200^{\circ} \mathrm{E}-\mathrm{N} 210^{\circ} \mathrm{E}$. Estimation of overburden and mineable coal reserves using the cross section method are: overburden volume is 1339886,283 BCM and mineable coal reserves is 459678, 6117 MT so that the value of Stripping Ratio obtained was 2.97
\end{abstract}

Keywords: Coal, mineable coal reserved, cross section method

\section{Introduction}

There are several coal reserve calculation methods that we often hear, which in this study will use the cross section method as the method used to calculate the M4 seam coal reserves at PT. Antang Gunung Meratus. Pit design for the December period PT. Antang Gunung Meratus refers to the stripping ratio set by the company.

The benefit of this research is to find out how to calculate coal reserves in the study area using the cross section method. Knowing how to design a pit based on the number of reserves with a target over burden and coal based on the stripping ratio set by the company. Companies can use the pit design that has been made as an actual design for December or just as a reference for the December pit design and as an information for other researchers to conduct further research.

The study was conducted at a coal mining company PT. Antang Mount Meratus. The research location is in the village of Idamanggala, Sungai raya sub-district, Hulu Sungai Selatan district, South Kalimantan Province. Geographically it was located at $114^{\circ} 51$ ' 19 " - $115^{\circ} 36^{\prime} 19$ " East Longitude and $02^{\circ} 29$ '58 " - $02^{\circ} 56^{\prime} 10$ " South Latitude. In this area lies the PT Antang Gunung Meratus PKP2B coal mining concession, KUD Karya Murnia and KUD Bina Iya. The location of PKP2B PT. Antang Gunung Meratus, namely in Block III S Warute, Block III S Waruba, Block IV Waruba, Block V and Block IV and included in Tapin District, Hulu Sungai Selatan and Hulu Sungai Tengah Regencies, South Kalimantan Province with an area of 22,433 Ha.

\section{Methodology}

The research was divided into 3 phases, namely the preliminary stage, the data collection stage and the data processing and analysis stage. 


\section{Method of Collecting Data}

The preliminary stage carried out in this research was the study of literature which aims to find literature relating to the Calculation of Coal Reserves using the Cross Section Method and pit design, and field observations aimed at observing the locations to which coal reserves will be calculated, observing topographical conditions and geology in the area.

At this stage, it was done by collecting data that was used for coal deposit modeling and calculation of mined reserves. The data will be used in this study such as topographic data, exploration drill data, boundary data, and recommendation data.

\section{Data Processing Method}

Data processing and analysis stages in this research were contour and solid topography modeling, cross section and coal cross section topography, reserve calculation, stripping ratio calculation, geometry design of mining pit design

\section{Results and Discussion}

\subsection{Topography}

Topography basically shows the surface conditions in the face of the earth and is usually displayed in the form of maps that use contour lines to show the surface conditions of an area. By paying attention to the topography in the study area we can find out how the surface conditions of the area. The topography in the study area is mostly in the form of lowlands which are shown with almost the same contour values and tenuous distance between contours, but also the presence of bounds marked by the distance between dense contours with elevated elevations. The research area is located in an area which has a height range of -65 to $112 \mathrm{~m}$.

\section{Spread of Coal Seam}

Based on the contour modeling data of the coal structure obtained from the mine plan department of PT. Antang Gunung Meratus and by referring to the 2-dimensional incision model data at the study site, the research area is known to have an M4 seam. Seam M4 itself in the direction of its distribution underwent Split into Seam M4A and Seam M4B where in M4A seam there was a split again, namely seam M4A1 and seam M4A2. M4A1 and M4A2 seams have split into M4A1A seam, M4A1B seam and M4A2A seam, M4A2B seam. Split is also found in M4B seam, M4B1 seam and M4B2 Seam.

Each seam shows the thickness of coal which varies, the structure of the layer that is bumpy and has a split (split). The slope of coal in the study area is generally relatively steep, in the range of $380-420$ with the strike direction N2000E N2100E.

\section{Modeling of Coal Deposits}

Coal modeling in this study was conducted by the mine plan department of PT. Antang Gunung Meratus where this modeling is basically intended to determine the direction of distribution, slope of coal and thickness of coal deposits in the study area. The management and processing of data from exploration drilling will give an idea of the condition of the coal deposit in PT. Antang Mount Meratus. In addition to modeling coal deposits, there are several outputs that are also modeled by the mine plan department of PT. Antang Gunung Meratus, this is needed as a reference in estimating coal reserves later, including:

- Model topography, namely data points in the form of easthing, northing, and elevation coordinates obtained from the results of a survey of actual conditions on the ground (earth's surface) in general will be modeled because it will be very necessary in making decisions related to estimated reserves, as well as indispensable in calculating coal reserves and estimating resources.

- Drill hole (section), in general in modeling the distribution of drill holes, survey and lithology data are needed obtained from the results of exploration drilling activities. But in this study, drill hole data provided is a data section (section) between topo with the distribution of drill points in the study area in the form of a drawing (dwg) file that can be accessed with auto cad or minescape software, so that it can be directly calculated the volume of coal reserves. But in general, to process drill hole data using Minescape software, the survey data required generally consists of drill hole ID, easting, northing, drilling elevation and total depth from the drilling point. While lithology data generally consists of drill hole ID, seam code, depth from, depth to, and lithology code. By processing both of the data on the Strattodel minescape product application, you will get a drill hol distribution model

- Structure contour modeling, where structural contour modeling is carried out as the roof structure contour and floor structure contour. Making the roof and floor contour will model the distribution of coal deposits that will be calculated reserves in the study area. Contour roof structure is the upper limit of coal deposits with rocks above it, saddle the contour of the floor structure is the lower limit of coal deposits with rocks below. In this study, the contours of the coal seam structure to be calculated have been given, so we only need to make an intersection with the latest topo (November), and we will get a reserve crossing limit that is in actual field conditions (cropline).

- Cropline Modeling, where the modeled cropline is a cropline from the coal floor. Theoretically cropline is defined as a line connecting the points between outcrops, whereas in actual conditions in the field Cropline is often interpreted as a pseudo line connecting the intersection points between the topographic contours with the contours of the coal structure. Cropline is used as a reference in making a mining pit design. 
- Cross section, to determine the condition of coal deposits or lithology in the study area, both the distribution and degree of slope and thickness of the coal, then cross section can be cut. Cutting done in this study is to make a direct line of dip coal or perpendicular to the cropline roof and coal floor in the study area. This can be shown through a cross section that is cut in certain areas. The results of the intersection will show the condition of the coal deposit in the form of the intersection appearance in 2 dimensions. So that it can be calculated directly the volume over burden, coal, and inter burden.

\section{Calculation of Coal Reserves}

In this research, reserve calculation is done by cross section method. Cross section is one of the classic methods in calculating the volume of minerals. Reserve calculation using the cross section method is done by drawing a number of cross sections in a fixed space (L) through the mineral deposit area, where the cross section is attempted perpendicular to the mineral deposit general streak. This method is an application of basic volume calculation, which is a calculation for a model that has three dimensions in the form of length, width and height. In applying the cross section method on a computerized system using the Mincomcape Minescape 4.1.1.9 or Auto CAD 2007 application, before making a calculation, some data must be made:

- Topography end of November.

- Cropline roof and floor seam M4.

- Made a perpendicular strike line cropline or line cut in the direction of the coal dip.

- $\quad$ Strike and coal dip.

- $\quad$ Overall slope highwa1.

After the five data above have been made then the next step is to carry out a backup calculation activity where the topographic data at the end of November is used as a surface. Cropline roof and floor are used as objects to be cut by a secant. Then after the roof topo and cropline and floor are cut off, it will appear a 2-dimensional plane showing the surface area and location of the coal roof and floor, after that draw the line in the direction of the Strike and the coal dip, the appearance of the outcrop of coal will be seen. After that, the outcrop area of coal can be measured and the formula calculated using the formula:

$V=\frac{S_{1}+S_{2}}{2} L_{1}+\frac{S+S_{3}}{2} L_{2}+\frac{S_{n-1}+S_{n}}{2} L_{n}$

Where:

L1, L2, L3, .. Ln = Distance between cross sections (m)

$\mathrm{S} 1, \mathrm{~S} 2, \mathrm{~S} 3, \ldots . \mathrm{Sn}=$ Area of each section $\left(\mathrm{m}^{2}\right)$

\section{Reserve Calculation Results}

By using the cross sectiom method in Mincomscape 4.1.18 or Auto Cad 2007 application, the calculation results can be seen in Table 1 below:

\begin{tabular}{|c|c|c|}
\hline Parameters & Value & United \\
\hline OB Volume & $15,971,352.430$ & BCM \\
\hline COAL Volume & $4,626,461.957$ & BCM \\
\hline COAL Tonnage & $5,378,262.025$ & TON \\
\hline
\end{tabular}

Table 1: The Results of Calculation of Reserves with Cross Section Using the

Topography of the End of November in the Pit Area B-III S Warute South (PT. BSS)

\subsection{Stripping Ratio}

From the results of processing and calculation in the Pit Area B-III S Warute South (PT. BSS) using the cross section method obtained coal tonnage on M4 seam was 5,378,262,025 tons with a total over burden of 15,971,352.43 BCM, then the ratio calculation the stripping ratio is as follows

Stripping Ratio $=$

(Total volume of overburden (waste)

(Total coal reserves)

$=(15,971,352.43$ BCM $) /(5,378,262,025$ Tons $)$

$=2.97$

It can be concluded that each stripping of 2.97 BCM over burden gets 1 Ton of coal. After obtaining tonnage of coal reserves in seam M4, it is only necessary to design the pit according to the December target set by the company, namely with overburden of 1,350,000 BCM, coal of 450,000 TON, and with stripping ratio 3 . In the actual design the mined reserves are obtained for the December pit was 459,678.61 tons of coal with an over burden of 1,339,886.28 BCM and had a SR value of 2.91 .

\subsection{Mining Design}

Based on the recommendations given by PT. Antung Gunung Meratus from the analysis of rocks in the pit, the geometry of the disign mining pit in the study area was determined, as shown in table 2 below: 


\begin{tabular}{|l|l|c|c|}
\hline \multirow{4}{*}{ high wall dan side wall } & \multicolumn{1}{|c|}{ Parameter } & Rekomendasi & unit (satuan) \\
\cline { 2 - 4 } & 1.Single slope & 60 & ${ }^{\circ}$ (derajat) \\
\cline { 2 - 4 } & 2.Bench high & 10 & $\mathrm{~m}$ (meter) \\
\cline { 2 - 4 } & 3.Berm width & 5 & $\mathrm{~m}$ (meter) \\
\hline \multirow{3}{*}{ low wall } & 1.Single slope & 30 & ${ }^{\circ}$ (derajat) \\
\cline { 2 - 4 } & 2.Bench high & 10 & $\mathrm{~m}$ (meter) \\
\cline { 2 - 4 } & 3.Berm width & 10 & $\mathrm{~m}$ (meter) \\
\hline ramp & 1. Lebar jalan & 25 & $\mathrm{~m}$ (meter) \\
\cline { 2 - 4 } & 2. Gradejalan & 8 & ${ }^{\circ}$ (derajat) \\
\hline
\end{tabular}

Table 2: Recommended Geotek Pit. Area B-III S Warute South (PT. BSS)

Pit designed for December has an elevation of $20-40$ on the contour of the floor. With 1,339,886.28 overburden and 459,678.61 coals with a stripping ratio of 2.91, the pit area for December was $10.94 \mathrm{Ha}$.

\section{Conclusions and Suggestions}

\subsection{Conclusion}

The conclusions that can be drawn from this research activity were:

- Total mined coal reserves that can be optimized for the Pit Area B-III S Warute South (PT. BSS) obtained coal tonnage on the M4 seam of 6,100,088,109 Tons.

- Total total over burden mined which can be optimized for Pit Area B-III S Warute South (PT. BSS) obtained coal tonnage on M4 seam amounting to 18,153,336.27 BCM.

- Based on the total coal s and the total volume of overburden that has been obtained in the Pit Area B-III S Warute South (PT. BSS), the stripping ratio value of 2.98 is obtained. So that the stripping of $2.98 \mathrm{BCM}$ over burden gets 1 Ton of coal. After obtaining tonnage of coal reserves in seam M4, the pit design is in accordance with the December target determined by the company, namely with overburden of 1,350,000 BCM, coal of 450,000 TON, and with stripping ratio

\subsection{Suggestion}

- If further research will be carried out then the calculation should be done using different methods such as triangle, blockmodel or polygon method for .comparison so that the accuracy of the research can be estimated.

- And the differences that occur can be used as a reference for choosing which method should be chosen by the company.

\section{References}

i. Aladin, A, Coal Natural Resources,Lubuk Agung, Bandung,1-5, 2011.CV. Your Graha IlmuBogor,136-137, 226, 233-235, and 239-242, 2014.

ii. Hartman, H. L., \& Mutmansky, J. M, Introductory Mining Engineering Second Edition, John Wiley \& Sons, Inc.,Hoboken,New Jersey,158-160,2002.

iii. Hustrulid, W., Kuchta, M., \& Martin, R.Open Pit Mine Planning \& Design CRC Press / Balkema, Rotterdam, Brookfield, 219, 222, 372,390, 2013.

iv. Ministry of Energy and Mineral Resources, Mining LaMineral and Coal, Fukusindo Mandiri, Bandung, 2-6, 2009.

v. Minerals Council of Australia, Australian Code For Reporting Of Identified Mineral

vi. Resources and Reserves, Australian Institute of Geoscientist,Australia,3- 9, 1996.

vii. Noor, D, Geology for Planning, CV. Grahallmu, Bogor, 117- 118,2011.

viii. Indonesian National Standards, Guidelines Reporting, Resources and Reserves Coal, National Standardization Agency,Indonesia,1-3, 2011

ix. Sulistyana, W, Mine Planning EditionSixth, Infonet Media, Jogjakarta. 7-8, 26, 22-23, 42-47, 53-54, 59- 64, 2015.

x. Tobing, R. L, Initial Study ofCoal and North Sumatra, Resource CenterGeology, Volume 2 No.3, 7- 8, 2007. 